\title{
Entrepreneurial Modes towards Information Technology Applications in Business during Pandemic Covid-19 Based on Indonesia SMEs' Stories
}

\author{
R I N Budisantoso ${ }^{* 1}$, A Sumarwan ${ }^{2}$ \\ ${ }^{1}$ Department of Economics, Faculty of Economics, Universitas Sanata Dharma, \\ Yogyakarta, Indonesia. \\ ${ }^{2}$ School of Accountancy, Queensland University of Technology, Brisbane, Australia. \\ E-mail: innugroho@usd.ac.id ${ }^{1}$
}

Submitted: 14 Jan 2022, revised: 25 Feb 2022, accepted: 28 Feb 2022

\begin{abstract}
This paper aims to identify entrepreneurial modes towards information technology applications in business during pandemic Covid-19 based on Indonesia SMEs' stories. This study uses a phenomenological approach in discerning 33 Economics students' reports on SMEs' ways in relating to social media platforms in the midst of the pandemic as relatively different business instruments driven by information technology along with their encounters to new opportunities within the novel landscape of business. The reports indicate a general pattern of three critical stages linked to entrepreneurial challenges namely in the first stage business distortion, in the middle-efficiency calculation, and finally available resources allocation. Using two factors i.e. learning capability of the business actors and the sophistication degree of information technology applications, the ways through which entrepreneurs relate to information technology within pandemic context can be identified into four types of mode namely adoption, adaptation, aversion, and abandon. Most of them are in adoption mode, few are in adaptation and abandon modes, and none are in aversion mode.
\end{abstract}

Keywords: entrepreneurial mode, information technology, SMEs, pandemic Covid-19

\section{Introduction}

Pandemic Covid-19 has been creating a new landscape of business, including those of SMEs' [1,2]. Within such context, business actors face a number of barriers and challenges regarding how to run businesses properly as well as maintain getting sufficient benefits from them through conventional business calculations to some extent have been in crisis responding to the novel atmosphere. At the same time, the application of various business instruments linked to information technology provides alternative ways in adjusting to the unprecedented condition.

Budisantoso, Sumarwan (Entrepreneurial Modes towards Information Technology Applications in Business during Pandemic Covid-19 Based on Indonesia SMEs' Stories) 
Some studies on the related issues within the pandemic have been conducted. For instance, Adam and Alarifi [3] develop a theoretical model in order to provide insights about the association between innovation practices and the SMEs' performance and survival linked to external support such a relationship within Saudi Arabia's environment. Sardar et al [4] investigate the impact of information communication technology on entrepreneurial self-efficacy, social networking, and facilitation to micro-entrepreneurs in the context of Pakistan. Polas and Raju [5] explore how technology influences entrepreneurial marketing decisions among a number of SMEs in Bangladesh. Concerning Indonesia's context, Purbasari et al [6] analyze the rise of digital entrepreneurship associated with SMEs' experiences.

The features on which business actors relate to the new environment along with information technology applications are understandable diverse considering the various backgrounds and paths of the businesses expressing the complexity of economic endeavors. To this issue, this paper aims to identify entrepreneurial modes of selected SMEs business actors, particularly within Indonesia's context, based on the stories collected by a number of Sanata Dharma University students. Entrepreneurial modes in this research are likely to be linked to the entrepreneurial ways in which technology takes significant influences on business actions, as stated by Stewart and Carayannis [7] as the abilities "to shift economic opportunities from established firms and industries to new ventures by the introduction or modification of new technology inventions or innovations."

The phenomenological approach is applied to the research because of two reasons. Firstly, the business sector associated with an entrepreneurial issue of business actors theoretically has personal meaning and interpretation. Therefore, as a field of study entrepreneurship has potential controversies. However, the application of this approach to entrepreneurial issues can develop a deeper understanding of such complications [8]. Though observed by some scholars as a method that lacks of precision $[9,10]$, this approach is widely viewed by other scholars compatible with particular situations with high quality of complexity such as business issues and entrepreneurship $[11,12]$.

The second reason is that currently one of the authors does facilitate dozens of young entrepreneurs in Yogyakarta and the surroundings, particularly in their efforts of developing ventures within a new landscape of business since the pandemic. Meanwhile, among the students at the Economics Department of Sanata Dharma University, there are some who do initial businesses by themselves as side-activities in parallel with their Economics online learning process during the pandemic. These personal involvements in entrepreneurial issues are linked to the researcher's personal understanding of the phenomenon by which a phenomenological inquiry is conducted [13].

To get a relatively clearer picture of entrepreneurial abilities under a phenomenological lens, this research focuses its exploration on the relations between two factors i.e. learning capability of the business actors and the sophistication degree of the information technology applications. Learning capability is seen as an internal resource of the business actors in their specific contexts, meanwhile, the sophistication degree of the information technology applications is a current challenge for the actors. According to Antonelli [14], the introduction of new technologies within particular businesses, in the Schumpeterian entrepreneurship perspective, can take place only if the business actors have the abilities in generating new knowledge through learning processes at the local baseline.

Here, situated learning theory by Jane Lave and Etienne Wenger [15] is useful to develop a purposive interpretation scheme towards selected SMEs' stories based on the relations between such two factors through the practices of learning. Moreover, the situatedness of the actors within their particular worlds is a key feature in the phenomenological approach [16]. Upon such various situatednesses, it is proposed that certain types of the entrepreneurial act can be recognized from the stories of how business actors struggle within their particular and available technological environments.

Budisantoso, Sumarwan (Entrepreneurial Modes towards Information Technology Applications in Business during Pandemic Covid-19 Based on Indonesia SMEs' Stories) 


\section{Method}

According to Abebrese [17], "entrepreneurship research intends to investigate the lived experiences of entrepreneurs through their narratives, stories, and anecdotes". Building upon this notion, phenomenological research of selected cases of entrepreneurial activities needs to pay attention to both descriptive and interpretive sides of the stories.

In doing such research, the data of this study is gathered through the following. Firstly, respondents are selected under this way. Every student chooses one SME in her or his particular area, which has proximity to her or his understanding and activity linked to entrepreneurship. 33 students during the pandemic have been in their particular residences spread across Indonesia (i.e. three locations in Sumatera, four in Kalimantan, one in Sulawesi, one in Bali, two in West Java, and the rests in several places in Central Java and Yogyakarta areas).

Secondly, the student does interview her or his respondent based on two main questions i.e. "What is the impact of pandemic Covid-19 to the business?" and "In what way does business actor use information technology applications, particularly social media platforms, in dealing with the current situation of the business during the pandemic?"

Thirdly, the stories of business actors composed by the students in two sections, namely (1) the actual condition of the business according to the business actor and (2) the student's opinion upon the aforementioned condition, especially in terms of how business actor making use of information technology applications. Therefore, we have 33 stories of SMEs with various characteristics, each added with the student's opinion.

Fourthly, the stories are collected and analyzed into three stages. The first stage of analysis is highlighting the respondent's point of view. The second stage is seeking a general pattern of all stories by recognizing the business condition through sequential paths i.e. (1) in the very beginning of the pandemic, (2) in the time afterward, and (3) in the time of going through. The last stage of analysis is identifying the entrepreneurial mode of each business actor associated with utilizing information technology applications within the business by employing four quadrants of two factors namely the learning capability of the business actor and the sophistication degree of information technology applications. The four quadrants depict certain entrepreneurial acts, i.e.:

1. Those who have high learning capability and utilize low-sophisticated information technology applications are in an adoption mode.

2. Those who have high learning capability and utilize highly sophisticated information technology applications are in an adaptation mode.

3. Those who have low learning capability and do not care about using low sophisticated information technology applications are in an abandoned mode.

4. Those who have low learning capability and resist using high sophisticated information technology applications are in an aversion mode.

\section{Results and Discussion}

There are 33 stories of SMEs composed by the students, as mentioned before. Most of them (23) are SMEs concerning in food and beverage businesses. Others have various concerns i.e. clothing businesses (6), handicraft business (1), cosmetics business (1), pet shop business (1), and supplement food business (1). Table 1 below shows how these SMEs undergoing their businesses during the pandemic, sequentially in the very beginning of the pandemic, in the time afterwards, and in the time of going through.

Budisantoso, Sumarwan (Entrepreneurial Modes towards Information Technology Applications in Business during Pandemic Covid-19 Based on Indonesia SMEs'Stories) 
Table 1. Condition of the SMEs in the beginning of the pandemic, in the time afterwards, and in the time

\begin{tabular}{|c|c|c|c|c|}
\hline No & $\begin{array}{l}\text { Type of } \\
\text { SME } \\
\end{array}$ & $\begin{array}{l}\text { In the Beginning of } \\
\text { the Pandemic }\end{array}$ & Afterward & $\begin{array}{l}\text { In the Time of Going } \\
\text { Through }\end{array}$ \\
\hline 1 & $\begin{array}{l}\text { Food \& } \\
\text { Beverages }\end{array}$ & Closing the store & $\begin{array}{l}\text { Reducing the number of } \\
\text { employees }\end{array}$ & $\begin{array}{l}\text { Online promotion } \\
\text { (Instagram) }\end{array}$ \\
\hline 2 & F \& B & Decreasing revenue & $\begin{array}{l}\text { Developing reselling } \\
\text { system }\end{array}$ & $\begin{array}{l}\text { Online promotion (Facebook } \\
\text { and WhatsApp) }\end{array}$ \\
\hline 3 & $F \& B$ & Decreasing revenue & $\begin{array}{l}\text { Finding new opportunities } \\
\text { in demand }\end{array}$ & $\begin{array}{l}\text { Online partnership } \\
\text { (GrabFood) }\end{array}$ \\
\hline 4 & F \& B & Decreasing revenue & $\begin{array}{l}\text { Finding new opportunities } \\
\text { in demand }\end{array}$ & Online promotion \\
\hline 5 & Clothing & Decreasing revenue & $\begin{array}{l}\text { Learning to develop a } \\
\text { digital marketplace }\end{array}$ & Online partnership (Shopee) \\
\hline 6 & F \& B & Decreasing revenue & $\begin{array}{l}\text { Learning to practice digital } \\
\text { marketplace }\end{array}$ & $\begin{array}{l}\text { Online partnership (GoFood } \\
\text { and GrabFood) }\end{array}$ \\
\hline 7 & Clothing & Uncertain demand & "Door to door" marketing & $\begin{array}{l}\text { Partnership with local } \\
\text { government }\end{array}$ \\
\hline 8 & Clothing & Decreasing revenue & $\begin{array}{l}\text { Reducing expenditure and } \\
\text { lowering price }\end{array}$ & $\begin{array}{l}\text { Online group } \\
\text { communication (WhatsApp) }\end{array}$ \\
\hline 9 & F \& B & Decreasing revenue & $\begin{array}{l}\text { Reducing the wage of } \\
\text { employee }\end{array}$ & $\begin{array}{l}\text { Online promotion } \\
\text { (Instagram) and online } \\
\text { partnership (GoFood and } \\
\text { GrabFood) }\end{array}$ \\
\hline 10 & F \& B & Closing the store & $\begin{array}{l}\text { Renovating the store to be } \\
\text { healthier to customers }\end{array}$ & $\begin{array}{l}\text { Online partnership } \\
\text { (GrabFood) }\end{array}$ \\
\hline 11 & $F \& B$ & Decreasing revenue & $\begin{array}{l}\text { Developing free delivery } \\
\text { mechanism }\end{array}$ & $\begin{array}{l}\text { Online promotion } \\
\text { (Instagram) }\end{array}$ \\
\hline 12 & F \& B & Decreasing revenue & $\begin{array}{l}\text { Collaboration with those } \\
\text { who have similar concern }\end{array}$ & Online partnership \\
\hline 13 & F \& B & Increasing demand & $\begin{array}{l}\text { "Mouth to mouth" } \\
\text { marketing }\end{array}$ & $\begin{array}{l}\text { Partnership with local } \\
\text { government }\end{array}$ \\
\hline 14 & $\begin{array}{l}\text { Supplement } \\
\text { Food }\end{array}$ & Decreasing customers & "Door to door" marketing & $\begin{array}{l}\text { Developing alternative } \\
\text { product }\end{array}$ \\
\hline 15 & F \& B & Closing the store & $\begin{array}{l}\text { Learning to use digital } \\
\text { platforms }\end{array}$ & Online partnership (GoFood) \\
\hline 16 & $\mathrm{~F} \& \mathrm{~B}$ & Closing the store & $\begin{array}{l}\text { Collaboration with those } \\
\text { who have similar concern }\end{array}$ & $\begin{array}{l}\text { Online partnership (GoFood } \\
\text { and GrabFood) }\end{array}$ \\
\hline 17 & F \& B & Decreasing revenue & $\begin{array}{l}\text { Developing selling system } \\
\text { by request }\end{array}$ & $\begin{array}{l}\text { Online promotion } \\
\text { (Instagram) }\end{array}$ \\
\hline 18 & Clothing & Decreasing revenue & Practicing the regularity & $\begin{array}{l}\text { Online promotion } \\
\text { (Instagram, Website, and } \\
\text { WhatsApp) }\end{array}$ \\
\hline 19 & F \& B & Closing the store & $\begin{array}{l}\text { Developing service system } \\
\text { from home }\end{array}$ & $\begin{array}{l}\text { Online promotion } \\
\text { (WhatsApp, Instagram, } \\
\text { Facebook, and Twitter) }\end{array}$ \\
\hline 20 & F \& B & Decreasing revenue & $\begin{array}{l}\text { Learning to practice digital } \\
\text { marketplace }\end{array}$ & $\begin{array}{l}\text { Online partnership (GoFood } \\
\text { and GrabFood) }\end{array}$ \\
\hline
\end{tabular}




\begin{tabular}{|c|c|c|c|c|}
\hline No & $\begin{array}{l}\text { Type of } \\
\text { SME }\end{array}$ & $\begin{array}{l}\text { In the Beginning of } \\
\text { the Pandemic }\end{array}$ & Afterward & $\begin{array}{l}\text { In the Time of Going } \\
\text { Through }\end{array}$ \\
\hline 21 & F \& B & Closing the store & $\begin{array}{l}\text { Minimizing operational } \\
\text { costs }\end{array}$ & $\begin{array}{l}\text { Online promotion } \\
\text { (Instagram) }\end{array}$ \\
\hline 22 & Clothing & Decreasing revenue & $\begin{array}{l}\text { Collaboration with those } \\
\text { who have similar concern }\end{array}$ & $\begin{array}{l}\text { Online promotion } \\
\text { (Instagram and Facebook) } \\
\text { and online partnership } \\
\text { (Shopee) }\end{array}$ \\
\hline 23 & $F \& B$ & Decreasing revenue & $\begin{array}{l}\text { Learning to use online } \\
\text { application }\end{array}$ & $\begin{array}{l}\text { Online partnership (GoFood } \\
\text { and GrabFood) }\end{array}$ \\
\hline 24 & Handicraft & Decreasing revenue & $\begin{array}{l}\text { Learning to use online } \\
\text { application }\end{array}$ & Online partnership \\
\hline 25 & Clothing & Decreasing revenue & $\begin{array}{l}\text { Finding new opportunity in } \\
\text { supply }\end{array}$ & $\begin{array}{l}\text { Online promotion } \\
\text { (Instagram, Facebook, and } \\
\text { WhatsApp) }\end{array}$ \\
\hline 26 & Cosmetics & Decreasing revenue & $\begin{array}{l}\text { Learning to use online } \\
\text { application }\end{array}$ & Online promotion (Tiktok) \\
\hline 27 & F \& B & Decreasing revenue & $\begin{array}{l}\text { Developing alternative } \\
\text { delivery order system }\end{array}$ & $\begin{array}{l}\text { Online promotion } \\
\text { (Facebook) }\end{array}$ \\
\hline 28 & F \& B & Decreasing revenue & $\begin{array}{l}\text { Learning to be more } \\
\text { creative }\end{array}$ & Online partnership (GoFood) \\
\hline 29 & $F \& B$ & Decreasing revenue & $\begin{array}{l}\text { Continuing online } \\
\text { application utilization }\end{array}$ & $\begin{array}{l}\text { Developing new digital } \\
\text { opportunity }\end{array}$ \\
\hline 30 & F \& B & Decreasing revenue & Practicing the regularity & Practicing the regularity \\
\hline 31 & $F \& B$ & Decreasing revenue & $\begin{array}{l}\text { Reducing the wage of an } \\
\text { employee }\end{array}$ & $\begin{array}{l}\text { Developing product that } \\
\text { supports immunity }\end{array}$ \\
\hline 32 & Pet Shop & $\begin{array}{l}\text { Starting a new } \\
\text { business }\end{array}$ & $\begin{array}{l}\text { Developing an actual needs } \\
\text { assessment }\end{array}$ & Online promotion \\
\hline 33 & $F \& B$ & Stagnant & $\begin{array}{l}\text { Collaboration with those } \\
\text { who have similar concern }\end{array}$ & $\begin{array}{l}\text { Online partnership } \\
\text { (GrabFood) }\end{array}$ \\
\hline
\end{tabular}

It is quite obvious, as seen in Table 1 above, that most of the SMEs have experienced wicked impacts of the pandemic. The reconfiguration of various social interactions during the pandemic, especially under physical distancing policy throughout the country, does not always meet with the business' usual mechanisms of the SMEs. Therefore, most of the SMEs have run into decreasing revenue, and some of them have to close their ventures. It seems that their actual business models are incompatible with the new landscape of social interactions during the pandemic. To some extent, the pandemic and its impacts on social life creates a kind of distortion and makes SMEs' usual business model lacking of relevancy. This distortion apparently needs to be responded by another kind of business model.

In the time of "afterward", in general, the SMEs seem to be learners of the current challenges and try to recognize new opportunities, including digital issues. In order to be still in contact with their customers during the implementation of the physical distancing policy, most of them employ "trial and error" mechanisms with consideration to the efficiency degree of their unusual economic endeavors. This efficiency calculation is believed to be able to secure their businesses and involves collaborating with those who have similar concerns as well as utilizing new instruments of business i.e. digital applications. 
Regarding how the SMEs went through during the pandemic, particularly in terms of utilizing information technology applications, those depend on business actors' habits and networks related to their existing experiences, knowledge, and skills in using digital equipment. Therefore, some of them make use of social media platforms, by which they have been familiar with, such as Instagram, Facebook, Twitter, and Tiktok. Others use WhatsApp. Another way is to be in collaboration with GoFood, GrabFood, and Shopee platforms. This choice is mostly related to the business actors' networks in which new information or new strategy of business can be obtained by them. Besides that, some of them also consider the ways by which potential consumers or broaden community have been practicing their habitual day-to-day communications, including in terms of how they meet daily needs. Several other business actors choose to work together with local government or are in their regular existing activities. The diverse tangible and intangible resources linked to business actors' digital experiences as well as how those resources are being allocated and organized do create a different path of the SMEs' going through.

Though most of them have already been familiar with digital media and gadgets, it is not a guarantee that they are able to use those instruments effectively for business purposes. A current study on internet utilization in Indonesia by Bachtiar et al [18] under SMERU Research Institute gives similar findings as shown in Table 2 below.

Table 2. Internet utilization in Indonesia, 2019

\begin{tabular}{llc}
\hline No & Internet Utilization & Percentage \\
\hline 1 & Social Media & 87.20 \\
\hline 2 & Getting Information/News & 66.90 \\
\hline 3 & Entertainment & 62.12 \\
\hline 4 & Getting Information for Learning Process & 25.86 \\
\hline 5 & Sending/Receiving Email & 13.94 \\
\hline 6 & Getting Information about Goods/Services & 13.69 \\
\hline 7 & Purchasing Goods/Services & 12.84 \\
\hline 8 & Financial Facility (E-Banking) & 06.47 \\
\hline 9 & Selling Goods/Services & 05.08 \\
\hline 10 & Others & 03.25 \\
\hline Source Susenas, 2019 (processed)
\end{tabular}

Source: Susenas, 2019 (processed)

Despite such fact, business actors' social life and networks actually provide resource persons who can help them to improve their capability. The condition of the pandemic to some extent encourages business actors and other stakeholders within the pandemic to be more collaborative in various ways, especially in utilizing digital media [19].

In sum, during the pandemic, a general pattern of three critical stages linked to entrepreneurial challenges related to those SMEs comes up. Those are in the first stage business distortion, in the middle-efficiency calculation, and finally available resources allocation. Such three critical stages generate an arena in which SMEs business actors as entrepreneurs seek new opportunities based on established means, resources, and economic institutions. Within the arena, technology takes a significant role in facilitating entrepreneurial goals of business [20, 21, 22, 23, 24].

When the SMEs' available resources allocations and organizations that create a different path of the going through are to be highlighted by each business actor's way in utilizing information technology applications, it is evident from the SMEs' stories that most of them (20 SMEs) are in adoption mode. They have high learning capability, as seen in their habitual activities in utilizing 
digital media and gadgets, and have no quite big barrier in shifting their habits from non-business oriented utilizations to the business-oriented one.

Meanwhile, nine of them (9 SMEs) are in adaptation mode. They have learning capability and, for the reason of developing their businesses further, remain in the way to increase their capability in managing higher sophisticated information technology applications. Fewer of them (4 SMEs) are in their stability. For them, utilizing information technology application to develop business in the time of pandemic is not an urgency. However, as seen in the stories, they do not resist in using gadget for daily activities. They just abandon such digital equipment for developing their businesses. By paying attention to their particular backgrounds and reasons, for example overaged group and quite satisfying for their offline business reorganizations, such option is understandable.

In addition, there are none of all business actors (0 SMEs) who have a specific resistance to the utilization of information technology applications. It gives the impression that, in general, for all of the business actors, information technology applications provide new opportunities for developing businesses since the pandemic. In broaden sense, it seems that in contemporary times, including within the pandemic, information technology is not viewed by business actors as merely a particular tool of business, but to some extent, it actually shapes the environment or ecosystem of the business itself. Those who have and do businesses in the current time, whether want or not, should relate their specific businesses to the technological ecosystem due to such an ecosystem does structuring and influencing the business [25, 26].

Such four types of modes are illustrated in Figure 1 below

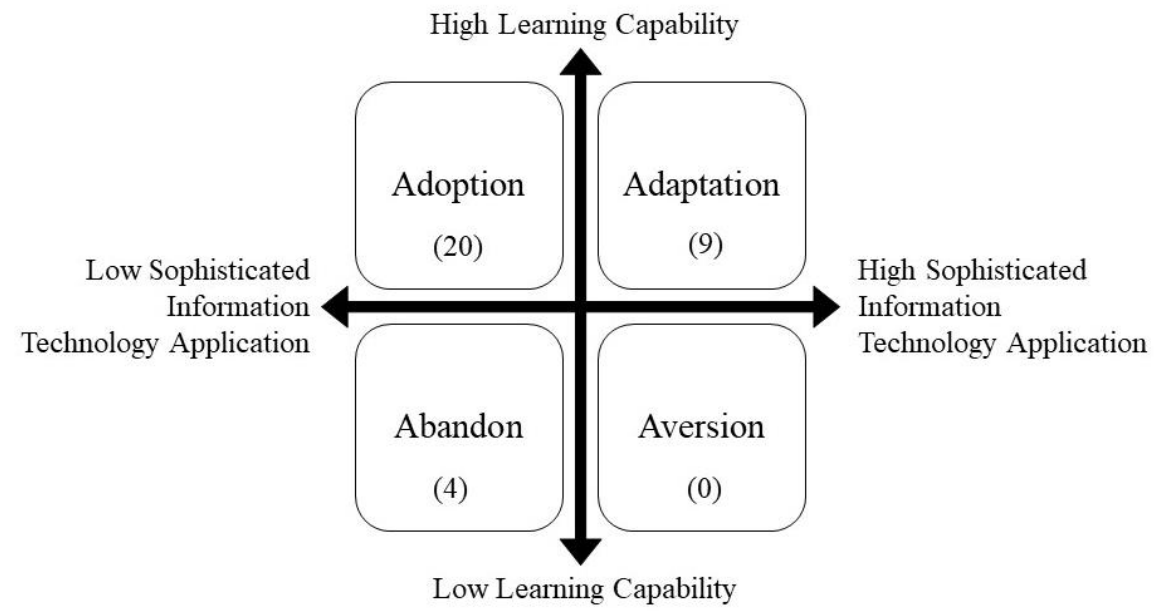

Figure 1. Four types of entrepreneurial mode towards information technology application in business among 33 SMEs during pandemic Covid-19

\section{Conclusion}

This research applying phenomenological lens has the purpose to identify entrepreneurial modes towards information technology applications in business during pandemic Covid-19 based on Indonesia SMEs' stories. There are various experiences on how the business actors deal with the pandemic that creates a new landscape of business. Commonly, they experience business distortion at first. Afterward, they look for efficiency, continuing with their available resources allocations and organizations. The entrepreneurial modes of them in terms of using information technology applications to create new opportunities for their particular businesses within the pandemic are linked

Budisantoso, Sumarwan (Entrepreneurial Modes towards Information Technology Applications in Business during Pandemic Covid-19 Based on Indonesia SMEs'Stories) 
to their existing habits and networks in making use of such applications. To do entrepreneurial acts, most of the business actors tend to adopt information technology applications by which they can deal with easily, and fewer of them are in adaptation to the more sophisticated applications associated with gaining more benefits. This indicates that SMEs business actors are familiar with digital media and gadgets, but remain in the struggle to engage and experience more appropriate advantages in digital economy institutions.

Due to the fact that within contemporary time technological ecosystem along with its various institutions and their dynamics does structuring and influencing businesses, particularly since the pandemic, there is an opportunity for further research in terms of identifying and analyzing various reciprocal relationships between ongoing developments of the digital ecosystem and business actors, especially those of SMEs, on the issues such as learning capability improvement strategic of the business actors and the characteristics of information technology applications which are in accordance with the contextual features of the business actors.

\section{Acknowledgement}

We thank Universitas Sanata Dharma for financially supporting this research. We declare that there is no conflict of interest related to the publication of this research results.

\section{References}

[1] V. Ratten, Ed., Covid-19 and Entrepreneurship: Challenges and Opportunities for Small Business, Oxon and New York: Routledge, 2021

[2] B. R. Hernández-Sánchez, G. M. Cardella and J. C. Sánchez-García, "Psychological factors that lessen the impact of COVID-19 on the self-employment intention of business administration and economics' students from Latin America," Int. J. Environ. Res. Public Health, vol. 17, no. 5293, 2020, https://doi.org/10.3390/ijerph17155293

[3] N. A. Adam and G. Alarifi, "Innovation practices for survival of small and medium enterprises (SMEs) in the COVID-19 times: the role of external support," J. Innov. Entrep., vol. 10, no. 15, 2021, https://doi.org/10.1186/s13731-021-00156-6e

[4] T. Sardar, Z. Jianqiu, M. Bilal and N. Syed, “ Information communication technology (ICT), technology acceptance model (TAM), entrepreneurial self-efficacy, ICT facilitation, COVID19,” Hum. Syst. Manag., vol. 40, no. 2, 2021, pp. 299-314

[5] M. R. H. Polas and V. Raju, "Technology and entrepreneurial marketing decisions during COVID-19," Glob. J. Flex. Syst. Manag., vol. 22, 2021, pp. 95-112, https://doi.org/10.1007/s40171-021-00262-0

[6] R. Purbasari, Z. Muttaqin and D. S. Sari, "Digital entrepreneurship in pandemic Covid 19 era: the digital entrepreneurial ecosystem framework," Rev. Integr. Bus. Econ. Res, vol. 10, supplementary issue 1, 2021, pp. 114-135

[7] M. R. Stewart and E. G. Carayannis, "Dystechnia: a model of technology deficiency and implications for entrepreneurial opportunity," Journal of Innovation and Entrepreneurship, vol. 2, no. 1, 2013, p. 1

[8] A. Abebrese, "Designing a phenomenological research model for entrepreneurship research," Int. J. Entrepreneurship and Small Business, vol. 22, no. 3, 2014, pp. 286-306

[9] J. C. Chamberlain, "Phenomenological methods and understanding education," in Existentialism and Phenomenology in Education, D. C. Denton (Ed.), New York: Teachers College Press, 1974, pp.119-138 
[10] P. Sanders, "Phenomenology: a new way of viewing organizational research," The Academy of Management Review, July, vol. 7, no. 3, July 1982, pp. 352-360

[11] H. Berglund, "Researching entrepreneurship as lived experience," in Handbook of Qualitative Research Methods in Entrepreneurship, H. Neergaard and J. P. Ulhøi (Eds.), Cheltenham and Northampton: Edward Elgar, 2007, pp.75-93

[12] A. Abebrese, "Research practice in entrepreneurship: a phenomenological approach," Int. J. Business and Globalisation, 2013

[13] V. M. Bentz and J. J. Shapiro, Mindful Inquiry in Social Research, Sage Publications, 1998

[14] C. Antonelli, The Knowledge Growth Regime: A Schumpeterian Approach, Palgrave Macmillan, 2019

[15] J. Lave and V. Wenger, Situated Learning: Legitimate Peripheral Participation, Cambridge University Press, 1991

[16] D. Moran, "The phenomenological approach," in The Oxford Handbook of Phenomenological Psychopathology, G. Stanghellini, A. Raballo, M. Broome, A. V. Fernandez, P. Fusar-Poli and R. Rosfort (Eds.), Oxford Handbooks Online, 2018, https://doi.org/10.1093/oxfordhb/9780198803157.013.26

[17] A. Abebrese, "Designing a phenomenological research model for entrepreneurship research," Int. J. Entrepreneurship and Small Business, vol. 22, no. 3, 2014, pp. 286-306

[18] P. P. Bachtiar, R. A. Diningrat, A. Z. D. Kusuma, R. A. Izzati and A. Diandra, Who Is Digital Economy for? Toward an Inclusive Digital Economy in Indonesia, Jakarta: SMERU Research Institute, 2020, https://smeru.or.id/en/content/who-digital-economy-toward-inclusive-digitaleconomy-indonesia

[19] M. J. Ibáñez, M. Guerrero, C. Yáñez-Valdés and S. Barros-Celume, "Digital social entrepreneurship: the N-Helix response to stakeholders' COVID-19 needs," The Journal of Technology Transfer, https://doi.org/10.1007/s10961-021-09855-4

[20] M. R. Stewart and E. G. Carayannis, "Dystechnia: a model of technology deficiency and implications for entrepreneurial opportunity," Journal of Innovation and Entrepreneurship, vol. 2, no. 1, 2013

[21] S. Nambisan, M. Wright and M. Feldman, "The digital transformation of innovation and entrepreneurship: Progress, challenges and key themes," Research Policy, vol. 48, no. 8, 2019, https://doi.org/10.1016/j.respol.2019.03.018

[22] World Economic Forum, Unlocking technology for the global goals. As part of Frontier 2030: Fourth Industrial Revolution for Global Goals Platform, 2020, https://www3.weforum.org/docs/Unlocking_Technology_for_the_Global_Goals.pdf

[23] A. N. Turi, Technologies for Modern Digital Entrepreneurship: Understanding Emerging Tech at the Cutting-Edge of the Web 3.0 Economy, Vancouver: Apress, 2020

[24] S. Pakura, "Open innovation as a driver for new organisations: A qualitative analysis of greentech start-ups," International Journal of Entrepreneurial Venturing, vol. 12, no. 1, pp. 109-142, 2020, https://www.inderscienceonline.com/doi/pdf/10.1504/IJEV.2020.105135

[25] R. Adner, "Ecosystem as structure: An actionable construct for strategy," Journal of Management, vol. 43, no. 1, pp. 39-58, 2017, https://doi.org/10.1177\%2F0149206316678451

[26] M. de Reuver, C. Sorensen and R. C. Basole, "The digital platform: A research agenda," Journal of Information Technology, vol. 33, no. 2, pp. 124-135, 2018, https://doi.org/10.1057/s41265-016-0033-3 